\title{
ENVIRONMENTAL CITIZENSHIP \\ FOR THE RATIONAL MANAGEMENT OF HOUSEHOLD AND SIMILAR WASTE IN THE CITY OF BEJAIA, ALGÉRIA (REPORT AND LIMITS)
}

\author{
Aid ABDELHALIM* \\ University of Salah Boubnider Constantine 3, Urban Techniques Management Institute, \\ La Nouvelle Ville Ali Mendjeli, Algeria, e-mail: abdelhalim.aid@univ-constantine3.dz

\section{Bouadam ROUKIA*} \\ University of Salah Boubnider Constantine 3, Urban Techniques Management Institute, \\ La Nouvelle Ville Ali Mendjeli, Algeria, e-mail: bouadam_rou@yahoo.fr
}

Citation: Abdelhalim, A., Roukia, B. (2021). Environmental citizenship for the rational management of household and similar waste in the city of Bejaia, Algéria (report and limits). Analele Universităţii din Oradea, Seria Geografie, 31(2), 167-177. https://doi.org/10.30892/auog.312107-869

\begin{abstract}
The problematic of rational management of household and similar wasteis a responsibility shared between all the actors of the city. The citizen or user has a great contribution in the success of this management. This by contribution to the realization of their duty and right in the collection of household and similar waste (HSW). The objective of this study is to examine the degree of enrollment of environmental citizenship in relation to the management of (HSW) in the collection and pre-collection phase in the city of Bejaia. The amount of waste generated in this city continues to increase $(0.84 \mathrm{Kg} / \mathrm{d} / \mathrm{Inh}$ abitant $)$, with a daily tonnage which reaches 191 tonnes. These quantities of household waste produced and thrown away daily appear dispersed and scattered randomly in the sectors of the city. This observation reflects the negative behavior of the inhabitants, and has caused several consequences on the living environment, and on the tourist vocation of the city in general. This does not allow the city to play its functionality and represents a discomfort in front of all users, and particularly a failure in front of the actors of this city. Resorting to the implementation of shared management will allow the city of Bejaia to strengthen the level of environmental citizenship. Thus, correct the level of offset in the collection phase.
\end{abstract}

Key words: environmental citizenship, rational waste management, user, living environment, city of Bejaia

$$
* \quad * \quad * \quad * \quad * \quad *
$$

\section{INTRODUCTION}

The evolution of consumption patterns and the limits inherent in our living space have become more pressing. Over time, the issue of waste has become increasingly problematic in particular because of its considerableincrease.Today, the discoure on the issue of waste management

\footnotetext{
${ }^{*}$ Corresponding Author
} 
proves significant and takes the first places in terms of challenge for cities. This for two fundamental reasons, the first concerns ecological questions; it is a question of knowing how to atrophy the negative impacts on the environment and on the quality of life of citizens. The second reason is purely economic related to the registration of a circular economy in the field of management of household and similar waste. The recourse of integrated waste management can help meet these two challenges, leading to a less fragile environment and considerable economic development.

A lot of actors are involved in waste management. They are involved in whole or in part, from the design and marketing of a product until its elimination. As a consumer, discarder, household waste collection user, and recyclable waste sorter, citizen or taxpayer, everyone can and must be an actor in better waste management. Each actor responsible for playing his role appropriately position in order to better realize effective management. The citizen is an essential factor in the waste management chain. His role begins in the pre-collection phase of household and similar waste. It can contribute to efficient collection on the one hand, on the other hand it can register inefficient collection by his behavior. The organization of collection can be greatly facilitated if the pre-collection is well designed Pre-collection or private collection of household waste includes all of the waste disposal operations from their place of production (housing) to pick-up location by a public collection service. This article examines this aspect from the angle of environmental citizenship.

For better approach the vision on the problematic of environmental citizenship and its relation to the registration of a relevant pre-collection of household waste, we have opted for the example of Bejaia City .A city known by its growing population and high density. Which have influenced the production of daily quantities of household waste.With the appearance of new materials and the overall change in consumption patterns; the composition of household and similar waste of Bejaia's inhabitants has also changed.

The citizen is a direct generator of waste, but also responsible for its disposal in places designated by the collection service. However, in the city of Bejaia, household and similar waste are scattered and dispersed in public spaces and not deposited in their own recommended places (in the reserved garbage bins). This observation has a negative influence on the living environment and the image of the city mainly when it is a tourist city. This situation affects the smooth running of the collection phase.

The success of the pre-collection of household and similar waste actually depends on the nature of the daily practices of the inhabitants (environmental citizenship). The inhabitants have the absolute responsibility of integration in the program underlined by the service of removal of household and similar waste in terms of collection through the respect of the schedules of taking out their household garbage and the deposit of this garbage in the places designated by the concerned departments.

\section{DEFINITION OF ENVIRONMENTAL CITIZENSHIP OR ECO-CITIZENSHIP}

The concept of eco-citizenship was born in Western countries at the end of the 1970s and became popular with the United Nations Summit on Sustainable Development in Rio in 1992.

This concept focuses on the need for individuals to have responsible actions and behaviors both in relation to their place of life and to their fellow human beings, especially future generations.

According to Ghandi, being an eco-citizen is "to live simply so that others can live".

According to Larousse, eco-citizenship is an individual or collective behavior consisting in observing the principles and rules intended to preserve the environment (Larousse, 2021).

Along with this definition of eco-citizenship, the notion of "responsible consumption" quickly appears.

"Responsible consumption is about giving an ethical sense and social utility to the act of buying. The consumer must become a "consumer", that means he shoud have a thoughtful purchasing process: he must no longer be passive in his act of consumption" (Vedura, 2021).

Thus, the basic principle of responsible consumption is to consume only if it is really necessary. 


\section{ENVIRONMENTAL CITIZENSHIP AND THE PRE-COLLECTION OF HOUSEHOLD AND SIMILAR WASTE: WHAT IS THE RELATIONSHIP?}

The severity of the problem of waste can vary and cause more significant impacts. That is why we must strive to consolidate environmental citizenship in urban areas. So that its integration takes place above all at the individual level Environmental citizenship is in a relationship compatible with the rational management of waste so that it contributes to the success of the various waste collection channels, in particular the pre-collection which starts from the private space (apartment).Some of them are inhabitants who have a high level of compulsory exercise of their environmental citizenship, and this aims to build their living environment.

Today, the increasing quantities of household and similar waste have dispersed in urban areas. These quantities caused odors and visual pollution. Thus, they put the image of the city in degradation. The citizen with his practices participated negatively to all observed effects, is considered the primary responsibility on this finding (increasing the dispersion of waste).

In order to have better disposal of these quantities of household and similar waste to their final destination, appropriate waste management should be highlighted. The organization of the precollection of household and similar waste is a constant connection with the practices reported by the user (resident, trader tourist...) The citizen who does not manage to take out his waste within the determined hours, he has no worries about his environment, he throws his waste away from the reserved bins, all these practices do not allow an effective pre-collection.

The relationship between environmental citizenship and the efficient pre-collection of household and similar waste is relatively correlated. It includs the level of responsibility of the inhabitant in ensuring that public spaces are healthy.

Secondly; environmental citizenship is always related to the living environment and quality of life of the inhabitants and marks an inseparable correlation and that from environmental citizenship we can consider and improve the living environment of citizens and put it back at the service ofan acceptable and relevant lifestyle. To this end we refer to all the reports that have initiated this notion.

Cutter, for example, defines it as "individual happiness or satisfaction with life and environment, including needs and wants, aspirations, preferred lifestyle and other tangible factors" (Cutter, 1985).

Schwab on the other hand sees that the quality of life does not understand only on the individual well-being but it extends to the collective objective conditions of the individuals, of which Schwab proposes that the quality of life "... is the difference between whatshould be and what is in a community; the difference between the goal and the evaluation, the measurement of the quality of life requires the analysis of the objective conditions, as well as the subjective evaluation of these conditions in a given place and their comparison between several places" (Bates, Murdie, \& Rhyne, 1996).

On the other hand, Mc Dowell and Newell affirm that the quality of life is an inseparable combination between material opportunities and the feelings of individuals: They suggest that it refers to "the adequacy between the material circumstances and the feelings of the individuals in relation to these circumstances" (Renwick, Brown, \& Nagler, 1996).

The protection of environement is the most factors in the dévelopment of tourisme (Sonko \& Deac, 2020). But it is not enough but citenzenship is also a key to make a city more attractive.

\section{THE ENVIRONMENT OF BEJAIA CITY}

With regard to the Algerian cities, the city of Bejaia manifests itself as a banner city, known for its tourist vocation, it has an environment which presents itself as a remarkable natural heritage (the national park of Gouraya, the lake of mezaia which comes to the heart of the city). It occupies a fairly growing population of around 190,181 inhabitants totaling all the municipality of Bejaia until the year of 2019 (Figure 1) (Monographie of City of Béjaia, 2010).

One of the factors that allows the city to play its tourist vocation is accessibility, it has benefited from the following four national roads (Béjaia City Administration, 2010):

- the NR 09 linking it to Sétif; 
- the NR 12 connecting it to Algiers Passing by Tizi-Ouzou;

- the NR 26 along the Soummam valley connecting it to Brouira where it joins the RN 05;

- the NR 24 connecting it to the wilaya of Algiers by the coast.

\begin{tabular}{|c|c|}
\hline Tourist potential & \multicolumn{2}{|c|}{ Industriel potential } \\
\hline \multicolumn{2}{|c|}{ Bejaia City } \\
\hline Privileged geographical location & Growing population \\
\hline
\end{tabular}

Figure 1. The characteristics of Bejaia City

(Source: Authors, 2021)

The population of the city of Bejaia has changed considerably. It estimated in the end of 2019 190,181 Inhabitants (National Office of Statistics, 2019). In 2008 it estimated a 177,998 inhabitants (National Office of Statistics, 2008), So the population of the municipality of Bejaia has evolved considerably, with an absolute increase of about 12,193 inhabitants and an increase rate of around $2.65 \%$, The population density is 1,546.18 inhabitants per km (National Office of Statistics, 2015).

The distribution of the population shows that $98.90 \%$ of the inhabitants live within the perimeter of the capital of the municipality, $0.26 \%$ in the secondary agglomerations.

The presentation of the set of characteristics of the city of Bejaia is based on the analysis by the SWOT method (assets, strengths, opportunities, weakness, and threats). This analysis allows us to bring out a series of issues concerning the city of Bejaia, thus, it will allow us to give several assessments that will be useful to take them into consideration, to point out the negative impacts on the living environment of citizens.

A summary table includes all the elements of this analysis are as follows (table 1):

Table 1. The city of Bejaia and its diversity: SWOT analysis

(Data source: (Béjaia City Administration, 2021) and authors' contribution)

\begin{tabular}{|c|c|}
\hline $\begin{array}{l}\text { Strengths (internal) } \\
\text { - Strength 1: La situation stratégique et privilégiée (un } \\
\text { paysage naturel plus côtier) } \\
\text { - Strength 2: La présence d'un véritable centre-ville, } \\
\text { identifiable et reconnu par ses habitants avec un grand } \\
\text { parc de logements, de nombreux services, des } \\
\text { équipements situés de manière équitable. } \\
\text { - Strength 3: Proximité d'un port et de l'aéroport (à } \\
\text { quelques minutes) } \\
\text { - Strength 4: un patrimoine naturel (la mer) et un } \\
\text { patrimoine historique important (la vieille ville). } \\
\text { - Strength 5: Une large gamme d'hôtels. } \\
\text { - Strength 6: Nombreuses ressources naturelles et grande } \\
\text { diversité écologique et paysagère. } \\
\text { - Population de plus en plus sensibilisée au thème de la } \\
\text { protection de l'environnement, à travers la présence d'une } \\
\text { multitude d'associations pour la protection de } \\
\text { lenvironement/ }\end{array}$ & $\begin{array}{l}\text { Weaknesses (internal) } \\
\text { - Weakness 1: The perimeter is entirely saturated and } \\
\text { urbanized, so it is difficult to intervene in the urban fabric. } \\
\text { - Weakness 2: An industrial zone which occupies a large } \\
\text { part of the urban fabric ( } 342 \text { ha), which represents a cut in } \\
\text { the sprawl of the city center, a door zone which results } \\
\text { from harmful effects on the environment. } \\
\text { - Weakness 3: Centralized management which slows } \\
\text { down local development in the city center. } \\
\text { - Weakness 4: The location of the stadium in the heart of } \\
\text { the city center shows strong co-management. } \\
\text { - Weakness 5: Lack of know-how in the valuation and } \\
\text { economy of heritage, } \\
\text { - Weakness 6: Degradation of historical and cultural sites. } \\
\text { - Weakness 7: appearance of quantities of uncollected } \\
\text { waste scattered throughout the city. }\end{array}$ \\
\hline $\begin{array}{l}\text { Opportunities (external) } \\
\text { - Opportunity 1: Beginning of the highway east-west ( } 03 \\
\text { lanes) which link Bejaia and Algiers, which will make the } \\
\text { city of Bejaia more attractive and economical. } \\
\text { - Opportunity 2: Important land bases will support the } \\
\text { overload (hypertrophy) of downtown Bejaia by the } \\
\text { commune of Oued Ghir. } \\
\text { - Opportunity 3: A great possibility of relocation of the } \\
\text { industrial zone to the municipality of EL-Kseur } \\
\text { (municipality of a commercial sale) reported to PADU } \\
\text { 2010. }\end{array}$ & $\begin{array}{l}\text { Threats (external) } \\
\text { - Threat 1 : Bad watersheds Controlled causes flooding } \\
\text { (oued Soummam). } \\
\text { - Threat 2: A significant number of newcomers from } \\
\text { neighboring municipalities, who want to build } \\
\text { spontaneously and illegally. } \\
\text { - Threat 3: The centralization of large-scale equipment } \\
\text { forces neighboring citizens to move hundreds of } \\
\text { kilometers, which causes congestion in the heart of the } \\
\text { city. } \\
\text { - The little-used local resources. }\end{array}$ \\
\hline
\end{tabular}




\section{MANAGEMENT OF HOUSEHOLD AND SIMILAR WASTE IN THE CITY OF BEJAIA: WHAT IS THE CONCLUSION?}

The accelerated urbanization, population concentration and economic development are factors that have amplified the production and deposit of urban waste. The problem of waste leads to an urban crisis, and represents a major challenge for the technical and administrative services by creating a certain dysfunction in the cities. According to the National Waste Agency: 12 million tonnes is the volume of household and similar waste at the national level in 2016 (Algerian National Waste Management Strategy, 2016).

The city of Bejaia, like other Algerian cities, suffers from the degradation of its environment. This situation has resulted in large part by the narrow waste disposal. High quantities generated without effective management have caused negative impacts on the urban environment (living environment) which has become of great concern in the city (Algerian National Waste Management Strategy, 2019).

The city of Bejaia is faced with; quantities of waste generated which continue to increase $(0.84 \mathrm{~kg} / \mathrm{d} / \mathrm{Inhabitant})$ and which represents 191 tonnes per day (Bejaia Waste Management, 2020). This observation constitutes an element which does not allow the city to play its functions; it has a negative influence on the well-being of users. Waste management presents itself as a failure in the eyes of city actors, who have failed to boost the local development in the city and put its tourist vocation in decline.

The issue of adequate management of household and similar waste is often mentioned in the city's good orders. It comes down to all the effects caused by this type of waste. Despite the wealth of the waste management policy and the regulatory framework in particular (Law $\mathrm{N}^{\circ}$. 01-19 of 12 December 2001 related to the management, control and disposal of waste on the management and control of waste) which represents a common thread for authorities (Algerian Ministry of Environment and Renewable Energy, 2020). However, at the organizational level, its implementation remains less applicable. Restricted management which sets aside the citizen (user). This latter, represents one of the keys players in the rational management of household and similar waste; It can help build a healthy living environment.

At the level of the city of Bejaia, the success of the management of household and similar waste focuses on the contribution recorded on the part of the citizens of the city of Bejaia. In other words, it reflects the nature of the environmental citizenship of the inhabitants. Based on this citizen report in achieving effective or ineffective management. Therefore, we opt to analyze the effects observed in the city of Bejaia in terms of household and similar waste; we report the daily practices of citizens towards the quantities of household waste generated per day. Thus, to measure the impact of all these practices on the living environment.

In order to identify the reality of environmental citizenship in the city of Bejaia and its role in ensuring adequate management of household and similar waste. We opted for a field survey among citizens of the city of Bejaia. This survey allows us to understand their opinions as well, to highlight all the acts noted in the management of household and similar waste in the city of Bejaia, in particular at the level of pre-collection and waste collection.

Therefore, we tried to treat the report of environmental citizenship in the management of household and similar waste (HSW) through a set of elements that are related to the usual practices of citizens in terms of management of (HSW) at the stage of pre-collection and collection and which led to the negative effects observed in the town of Bejaia.

\section{THE FREQUENCY (HOURS) EXIT (HSW) FROM THE TOWN OF BEJAIA}

In the logic of the collection of (HSW) citizens have a reasonable degree to throw (frequency of taking out the garbage) their quantities of waste generated in the reserved spaces (bins) in all the operations of the pre-collection. The collection of household waste by citizens must be fully coordinated with the schedules of the collection service. Obtaining the assurance of this coordination expresses the degree of environmental citizenship of the inhabitants. 
Concerning the frequency and the output schedules (HSW) by the inhabitants of the town of Bejaia is estimated to approximately $61.29 \%$ of the inhabitants are out waste every day. This value represents the total average of the city. This witness has given special attention to the production of waste deposit in the city of Bejaia. Having this relatively high frequency (61.29\% each day) will push us to think about the adequate collection of these generated quantities or their outputs by the inhabitants themselves. Thus, to ask the question on the relationship between this output frequency of (HSW) and the means used (number of rotations) by the cleaning center of the municipality of Bejaia in the collection. Secondly, there is a category of $28.54 \%$ of the inhabitants of the city of Bejaia take out their waste every two days, this finding remains worrying and does not give the collection phase a good function (Figure 2).

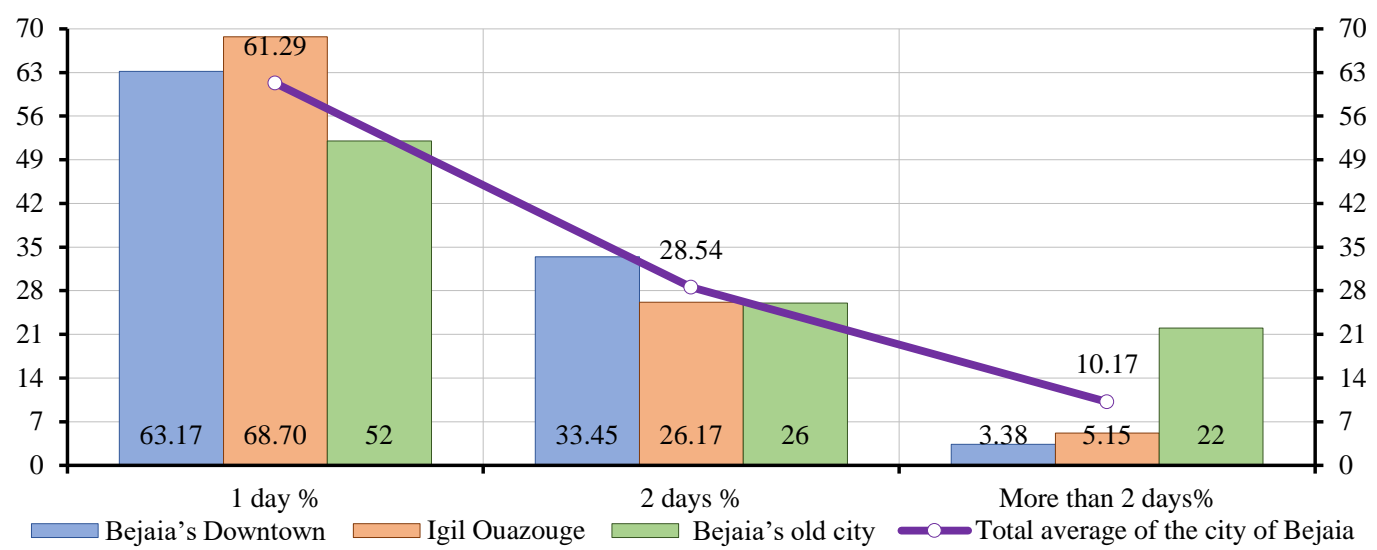

Figure 2. The frequency (hours) exit (HSW) from the town of Bejaia

(Source: authors, field survey, 2021)

The reason behind this high frequency is that cleanliness among residents is concentrated at the apartment level; without thinking about the cleanliness of the outside of the building. This observation led us to record the question of the cleanliness of the common space in the city of Bejaia. It appears narrow and is not in the service of a healthy living environmen.

\section{RATE OF COMPLIANCE WITH WASTE (HSW) OUTPUT SCHEDULESFROM THE TOWN OF BEJAIA}

In the issue of management of (HSW) a good collection can facilitate the phase of transport of the waste, thus registering a better disposal towards the final destination. The citizen can be an effective contributor who can make a certain degree of success in the collection of household and similar waste in his neighborhood or in his sector. This success lies in the respect by all the inhabitants of the exit times of their waste and to put it in the places kept for collection. This practice should be done almost at the pre-collection level. In the city of Bejaia and during the survey carried out in the field, a rate of $51.47 \%$ deplores the non-respect of the unloading schedules of household and similar waste on the part of the inhabitants (Figure 3). This observation is absolutely recorded in commercial and craft activities. All traders do not have a specific deadline for disposing of their waste (cardboard boxes in particular) and have made a considerable gap with the deadlines for the collection service. As a result, this practice always caused overflows in the trash cans and they always seemed full. These practices have resulted in visual pollution in the city.

At this stage of analysis, the collection of household and similar waste is not only based on the operation of an adequate collection plan by the cleaning center of the municipality of Bejaia, but indeed on the degree of respect for residents of their waste exit schedules. Strictly at the precollection level. 


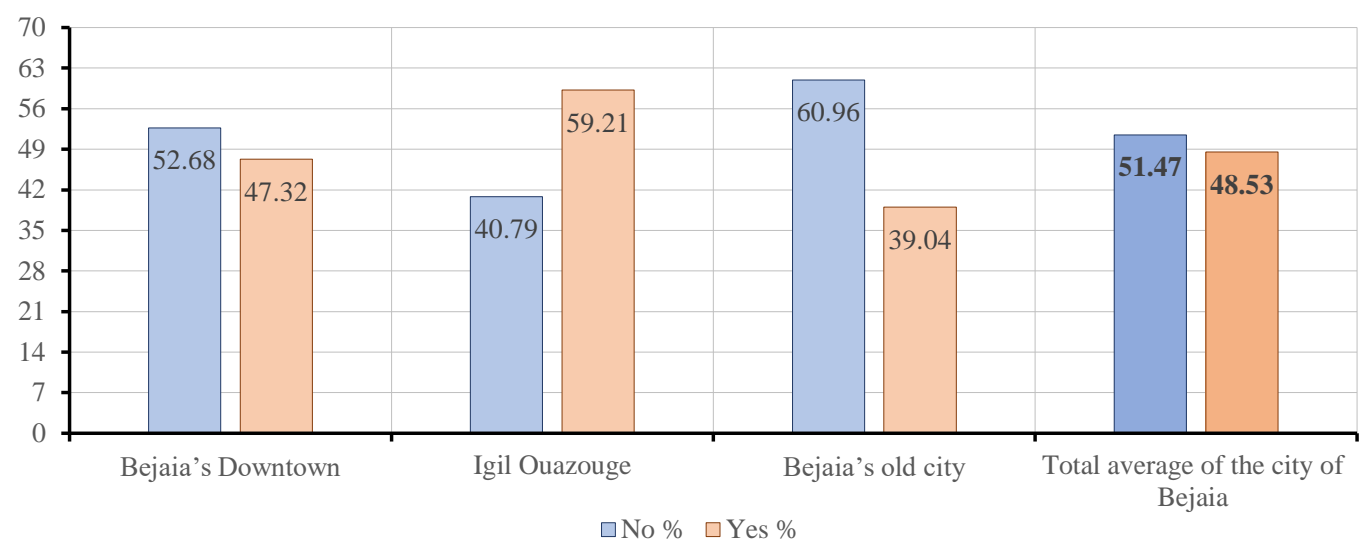

Figure 3. Rate of compliance with household waste disposal schedules (Source: Authors, field survey, 2021)

The success of the household and similar waste collection phase has a strong correlation with the respect of waste exit schedules on the part of the inhabitants of the city of Bejaia. So we see that the pre-collection operation is not limited to the exit of household and similar waste, but indeed to show a certain respect for exit times.

THE QUANTITY OF HOUSEHOLD AND SIMILAR WASTE PRODUCED PER DAY FROM THE TOWN OF BEJAIA

The report of the production of household and similar waste in the city of Bejaia is presented in three categories. A category that produces less than one $(-1 \mathrm{~kg})$ per inhabitant per day $(-1 \mathrm{~kg} /$ inhabitant/day) represented on the diagram with a rate of $46.43 \%$ as the total city average. This shows that the city of Bejaia is approximately in the national average of the country $(0.8$ kg/d/inhabitant) (Algerian National Waste Management Strategy, 2020) (Figure 4).

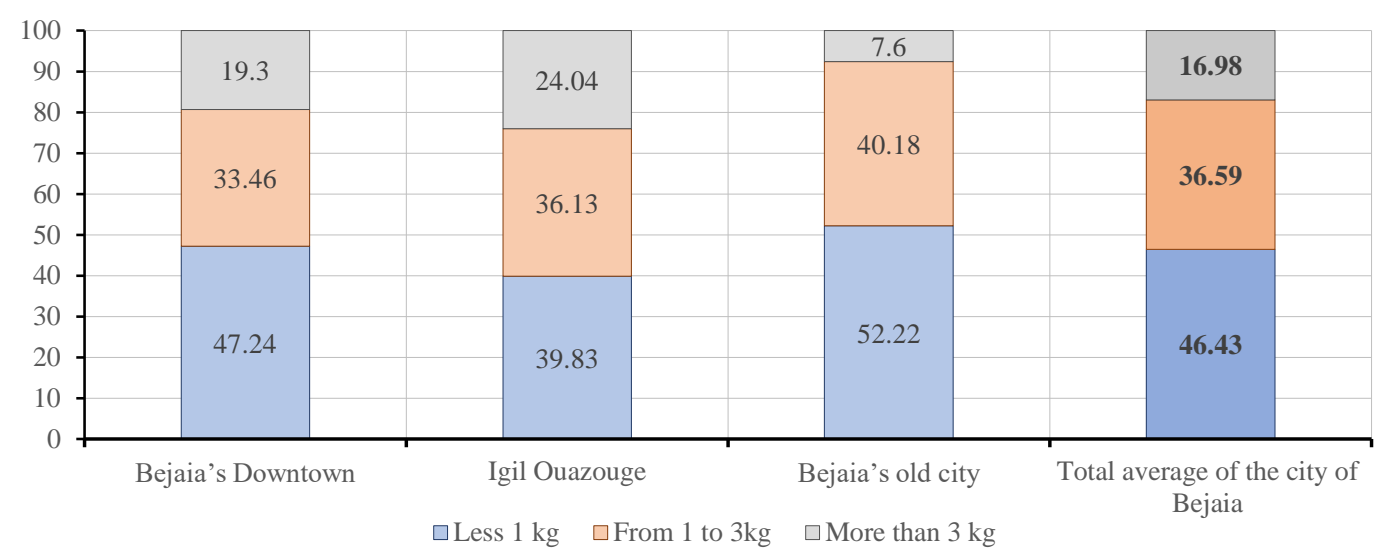

Figure 4. The amount of householdwaste produced per day

(Source: Authors, field survey, 2021)

The ratio of the production of household and similar waste in the city of Bejaia is relatively influenced by a set of factors, of which we summarize:

Population density by sector; this is the case for the area of igil ouzaough which has a high population density: 
- Household income, which influences the consumption pattern and the quantities of household and similar waste per household;

- The vocation of the city of Bejaia, as being a tourist city, household and similar waste can have extreme productions during the summer periods.

The determination of the quantity generated per day per inhabitant per kilogram in the city of Bejaia, plays a considerable role in the design of a collection plan by the authorties responsible for the collection of household and similar waste. When the authorities responsible for the collection of household and similar waste have a perception of the sectors which have a high frequency of waste exits on the part of the inhabitants (every day). They will arrive at a reasonable distribution of material and human resources for each sector.

\section{THE COMPOSITION OF (HSW) GENERATED FROM THE TOWN OF BEJAIA}

In the logic of the management of household and similar waste, knowledge of the composition and characterization of the household waste generated is considered an essential step. It allows a better classification of waste to be buried, incinerated or reclaimed and composted which are of economic interest. The diagram (figure 5) represents the rates of the composition of household and similar waste in the city of Bejaia through the three sectors taken into consideration:

- In first position comes the organic matter which is majority in the composition of household and similar waste with a rate of $51.38 \%$. This comes down to the consumption mode of the inhabitants;

- In the second position of composition of household and similar waste in the city of Bejaia is plastic with a rate of $23.87 \%$ (product packaging).

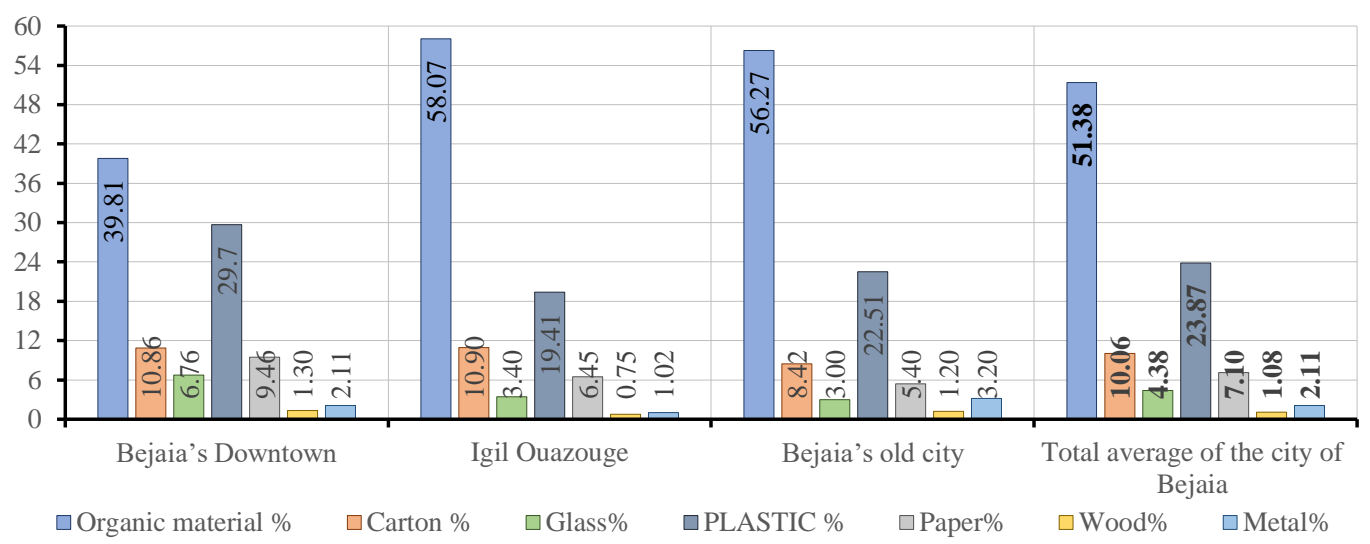

Figure 5. The composition of (HSW) generated from the town of Bejaia (Source: Authors, field survey, 2021)

Having a relatively dominant rate of organic matter in the composition of household and similar waste in the city of Bejaia, prompts us to reflect on the final destination of this type of household waste. In the city of Bejaia, all of the (HSW) produced are evacuated to the wild landfill at the seaside (boulimat) and they have put intoxication in less healthy fragility. To this end, residents are responsible for recording this finding.

THE LOCATION OF THE GARBAGE BINS HSW FROM THE TOWN OF BEJAIA:

The collection of household and similar waste depends on the mobilization of material resources. It includes all the pre-collection equipments installed in the residents' residences (garbage bins). The location of the garbage collection bins can help control collection operation that is why it 
was necessary to find suitable locations to place these bins in accordance with the needs of citizens. As a result, we can achieve efficient pre-collection of waste.

The results of the survey led us to classify and present the different opinions of the inhabitants of the city of Bejaia, and gave us an overview of the extent and level of their satisfaction with the disposal of the garbage bins of the waste in residential areas. The results are shown in the diagram (figure 6). The city of Bejaia's total average for the location of the garbage bins across the city is presented by a rate of $60.72 \%$ of the population satisfied with the location of the garbage bins throughout the city. In contrast, a rate of $39.27 \%$ of residents are not satisfied with the location of the garbage bins and do not respond to effective pre-collection of waste according to them. Most are citizens who are engaged in commercial activities. They consider that the garbage bins are far from their place of exercise (figure 8).

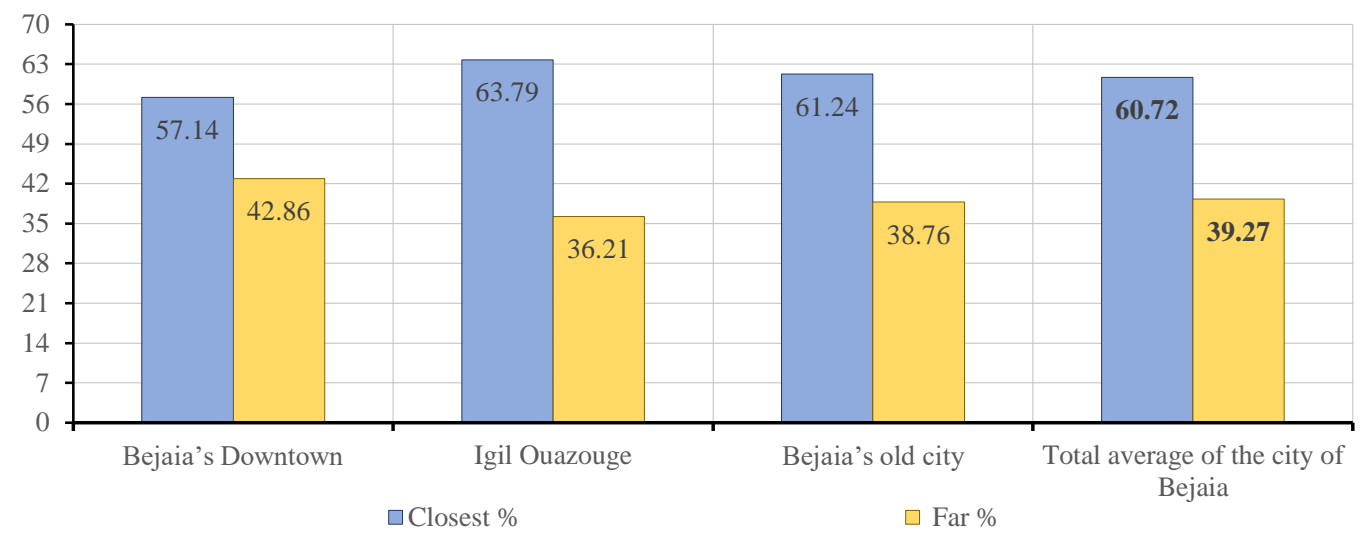

Figure 6.The location of the garbage bins HSW (Source: Authors, field survey, 2021)

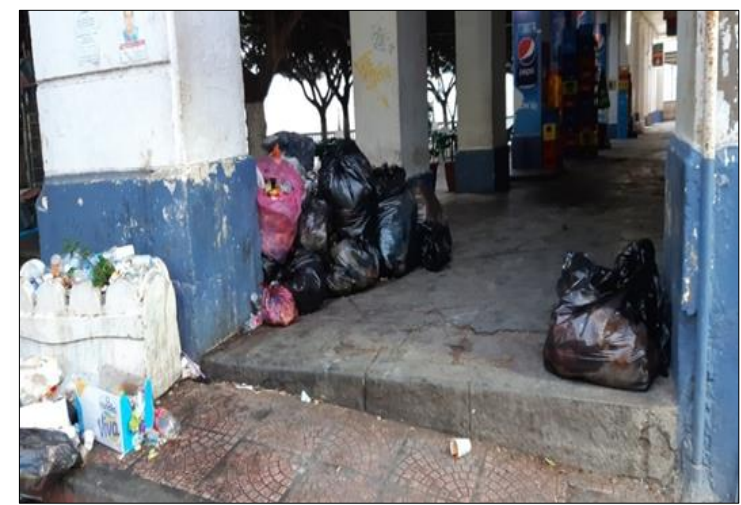

Figure 7. Waste from commercial activities not disposed of in installed bins (Source: Authors, 2021)

\section{ANARCHIC SCATTERING OF HOUSEHOLD AND SIMILARWASTE ACROSS THE CITY OF BEJAIA}

Citizens by nature want a clean living environment that is unaffected by various environmental impacts. But absolutely no one wants to accept that dispersionwaste throughout the city is the result of the (practical) behavior of each user of the city (citizens, inhabitants, tourists, traders). Household appliances in neighborhoods are considered to be an influencing factor and have multiple consequences on the living environment. The citizen with his different behaviors and 
practices contributes to the dispersion of this waste and causes pollution. By this behavior, he harms the image of the city. Therefore, in order to underline this phenomenon of random diffusion and to determine its different effects, we have mentioned this problem in the city of Bejaia.

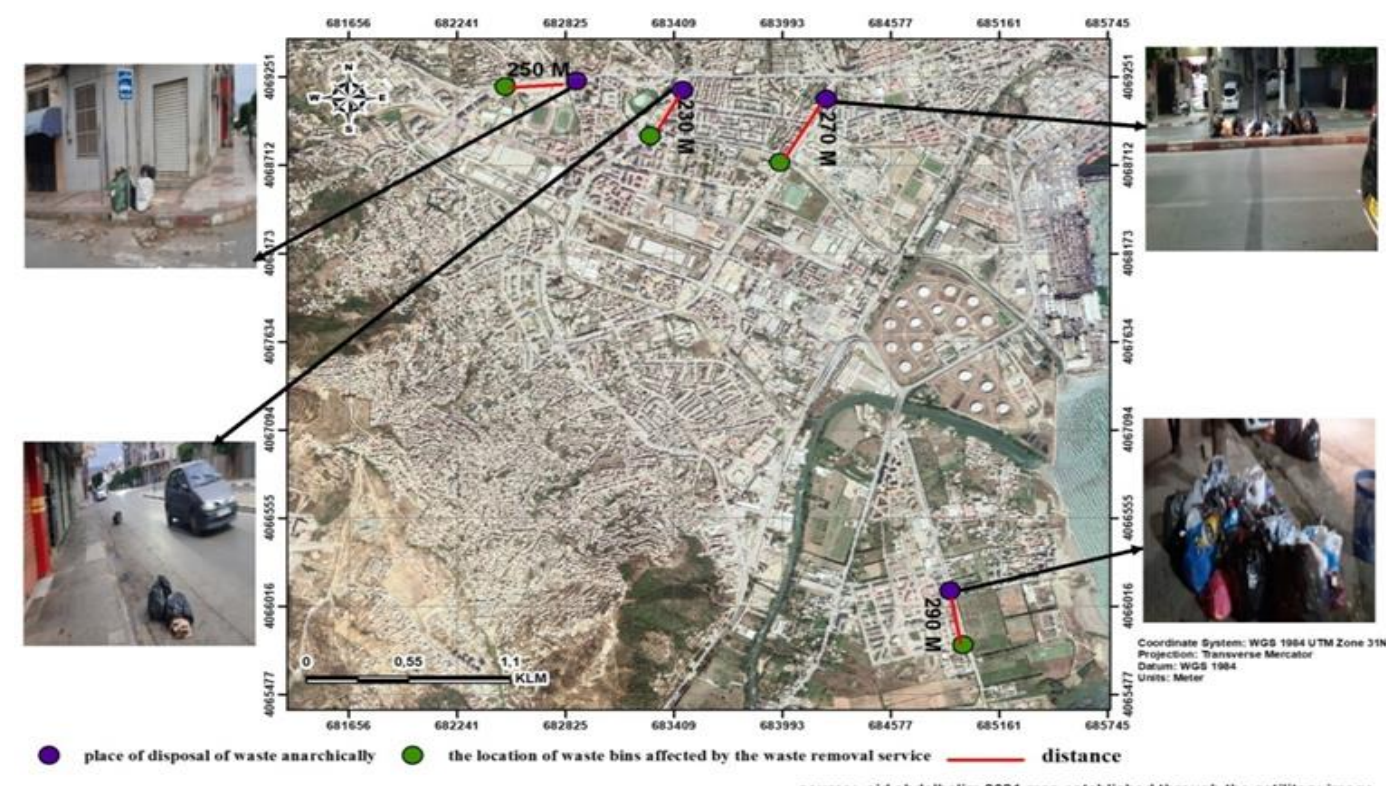

Figure 8. Impact of the inadequate location of the bins on the uncontrolled discharge of waste in the city of Bejaia.

(Source: aid abdehalim 2021.map establishes through the satilitary image and authors' contribution)

The inhabitants of this city declared that this phenomenon is presented by severity and does not serve to make the well being of the people in the city. This severity is presented by a rate of $55.34 \%$ comes as a total average for the city of Bejaia (Figure 9).

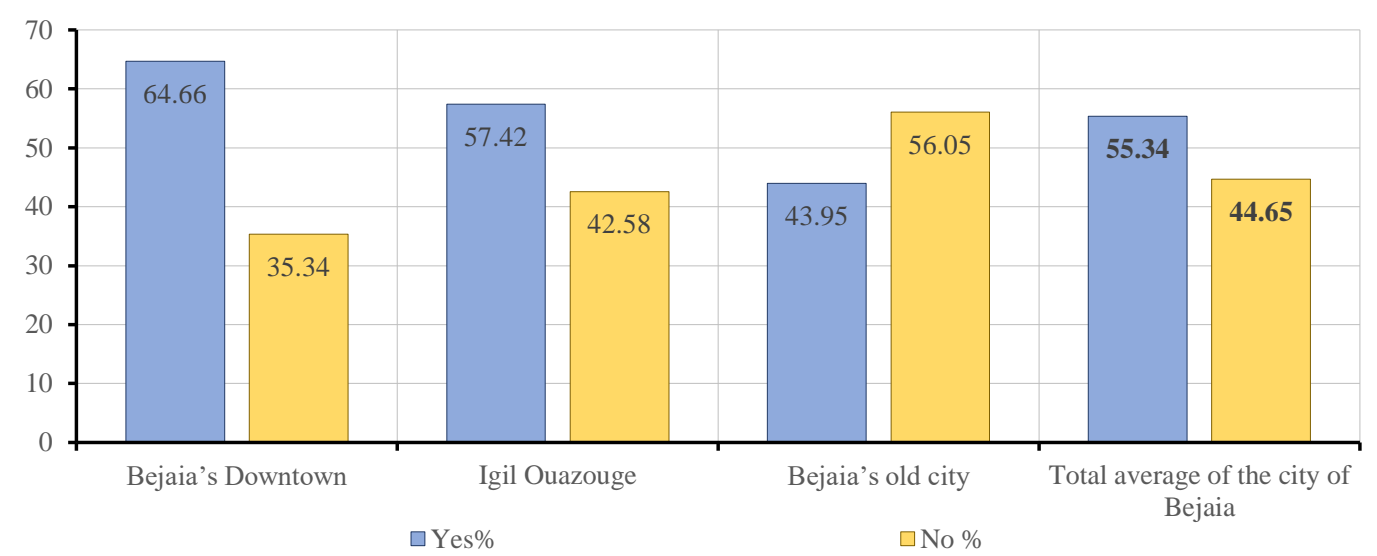

Figure 9. Citizens' opinions on the scattering of household and similar waste in the city of Bejaia (Source: authors, field survey, 2021)

Faced with this alarming observation, a set of behind factors resulted from this scattering of household and similar waste in the city of Bejaia. Of which it has been recorded: that the dispersion of waste caused by: 
- The use of fast food in all of the city's boulevards and especially at bus stops and at the bus station observed among all users.

- The considerable attractiveness of the city for users.

- Lack of respect for the household and similar waste exit schedules of a certain number of city residents (uncivil practices of individuals).

- The schedules of the exit of waste resulting from commercial activities which make a considerable difference contributed to register this mediocre image of the city.

- Having discrepancies in the collection from the cleaning center of the municipality of Bejaia almost contributes to the appearance of the phenomenon of scattering of household and similar waste in the city.

Therefore, in order to reduce the severity of random waste scattering, it is recommended that citizens change their behavior.

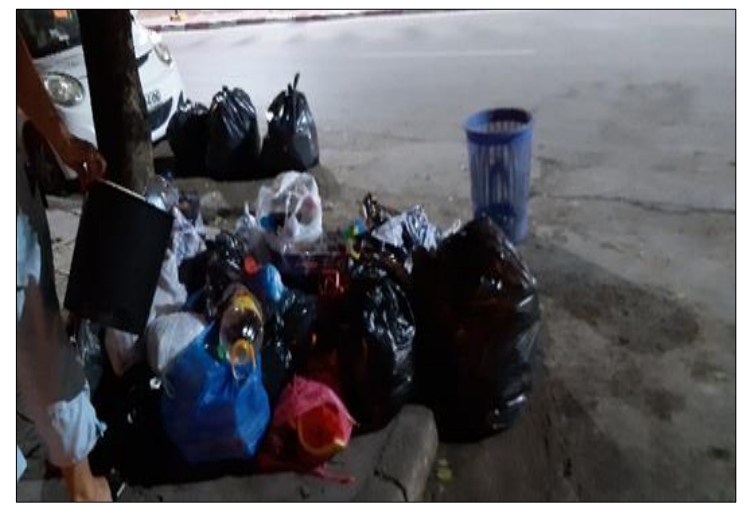

Figure 10. Spreading HSW through the city of Bejaia (Source: authors, 2021)

\section{FACTORS OF HSW SCATTERING ACROSS THE CITY OF BEJAIA:}

The random scattering of waste in the city cannot be limited to single factor urbanization and the behavior of citizens, but there are other factors that cannot be overlooked such as the method of waste management by the authorities concerned.

A set of factors behind the scattering of household and similar waste in the city of Bejaia.In order to better classify all of these factors, we opted to have the opinions of the inhabitants of the city, the results of which we have in the diagram (Figure 11)

- A rate of $46.45 \%$ of the inhabitants of the city of Bejaia declared that the scattering of household and similar waste is a result of a lack of civility of certain users noticed in the operation of the pre-collection, and the principle of the cleanliness of the external environments and in common is less affirmed;

- Secondly some residents have questioned the deficit recorded in the agency responsible for the management of household and similar waste; the testimony came to $30.36 \%$ of total residents.

Therefore, the reality is that we are faced with a conflict of a citizen or user who will play their right and duty in terms of the management of household and similar waste in the city of Bejaia. We need a resident who respects the rules of the environment and a healthy living environment. The assurance of this challenge lies in the empowerment of citizens towards their duties. Thus, and the promotion of citizen behavior through awareness, information, and involvement. However, as part against the agencies responsible for management have the responsibility to ensure a certain level of cleanliness in the city of Bejaia; by implementing effective management of household and similar waste and putting an end to all the discrepancies observed. 


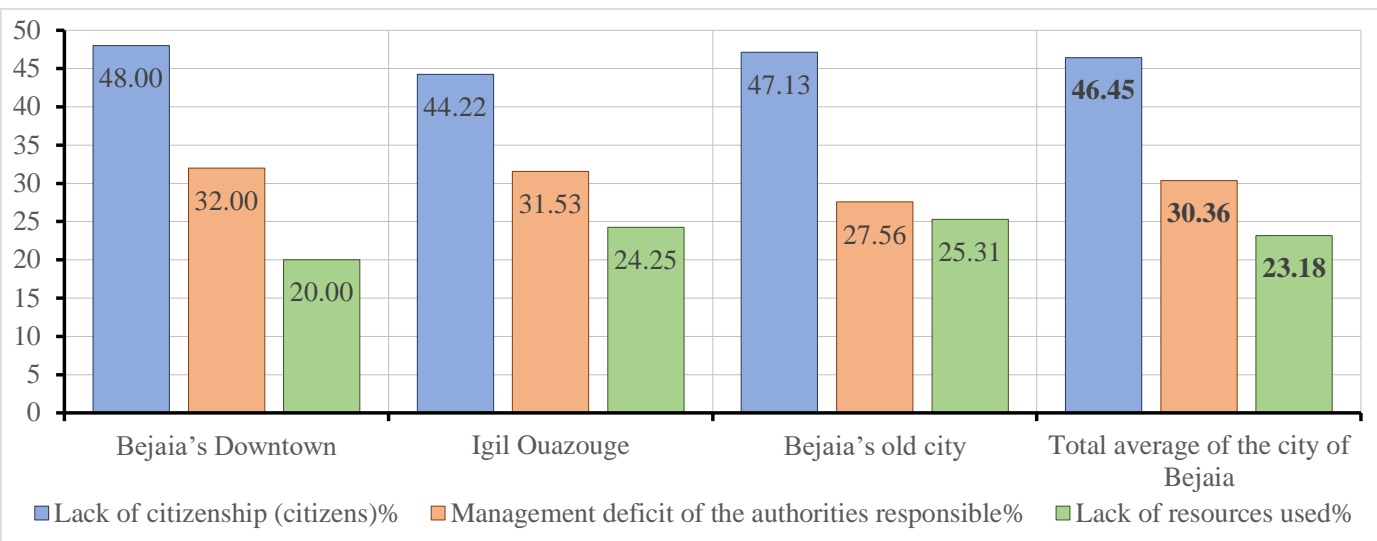

Figure 11. Factors of HSW scattering across the city of Bejaia (Source: authors, field survey, 2021)
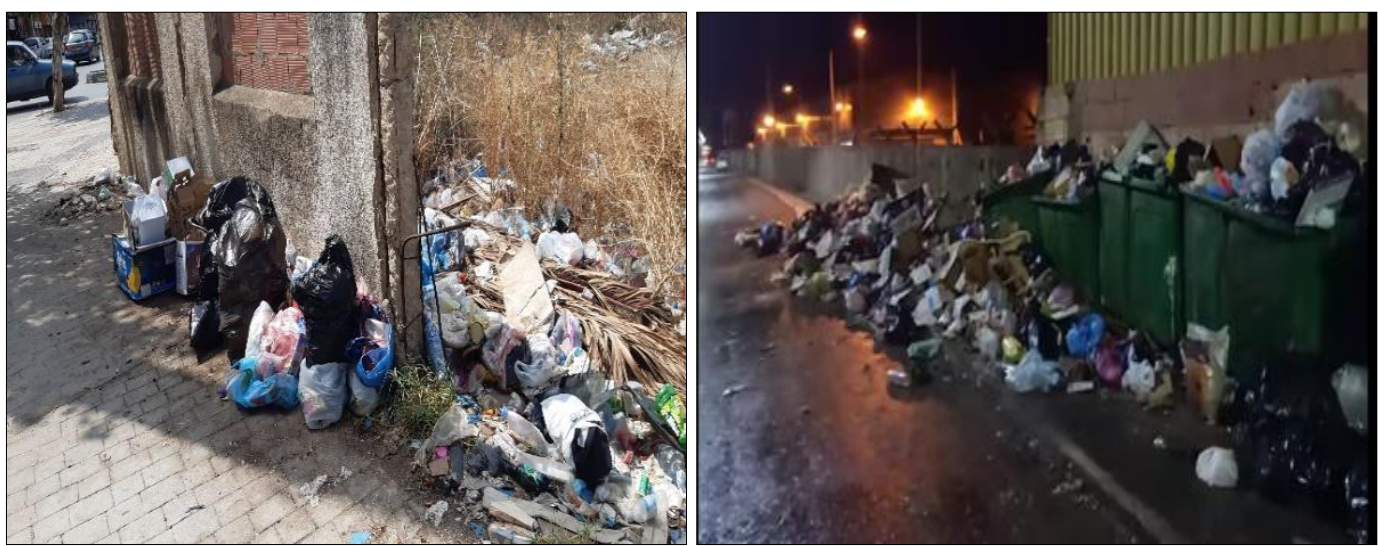

Figure 12. Dispersion of household and similar waste in view of all inhabitants in the city of Bejaia (Source: authors, 2021)

THE CONSEQUENCES OF SCATTERING WASTE THROUGHOUT THE CITY OF BEJAIA

Several urban facts have the degree of impact on recording progress or creating gaps in the city. The problem of the management of household and similar waste plays a large part in the achievement of this progress in the city and contributes massively in the construction of the image of the city (tourism promotion) this comes back to setting up a rational management of household and similar waste. However, other cities suffer from the problem of household and similar waste management and are experiencing poor results.

A result of a management deficit. In this present study, we have analyzed the impacts of the poor management of household and similar waste in the city of Bejaia, through the analysis the consequences of dispersion and accumulation waste. All the inhabitants of Bejaia City deplored that poor waste management has a negative impact on their living environment.

This observation, confirmed by a rate of $46.2 \%$, comes from a total city average over their various sectors Another considerable part of the population of the city of Bejaia declared that the poor management of household and similar waste has repercussions on the tourist vocation of the city represented by a rate of $35.89 \%$ of the total inhabitants of the city. Of which, they focused on the wild landfill of Boulimat which is located by the sea and on a site classified as a tourist site (figure 13). 
At this level of analysis, we see that the living environment and the tourist vocation of the city of Bejaia are less secure and call for their development. The shared management of household and similar waste in the city of Bejaia can revitalize the tourist vocation of the city and mark an acceptable living environment. The shared management in the management of household and similar waste resides on the encouragement of the associative movement in order to record the notable behaviors of the inhabitants, thus resides on the widening level of responsibility of the organizations responsible for the management of households and similar waste in the city of Bejaia, and correct the level of mismatch in management.

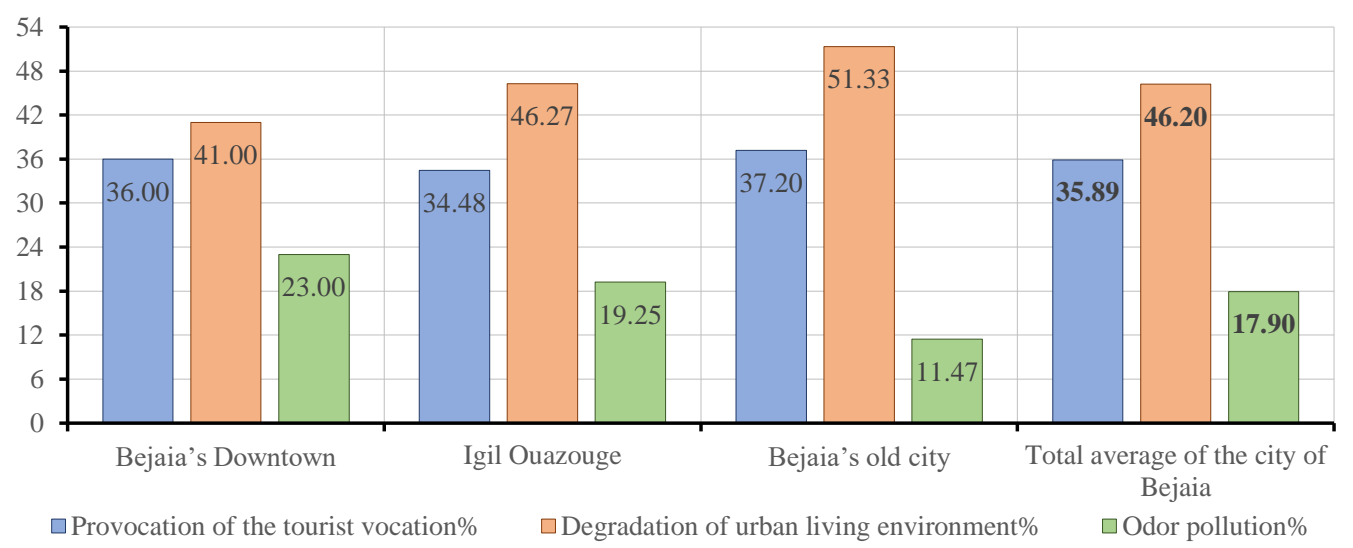

Figure 13. The consequences of scattering waste throughout the city of Bejaia (Source: authors, field survey, 2021)
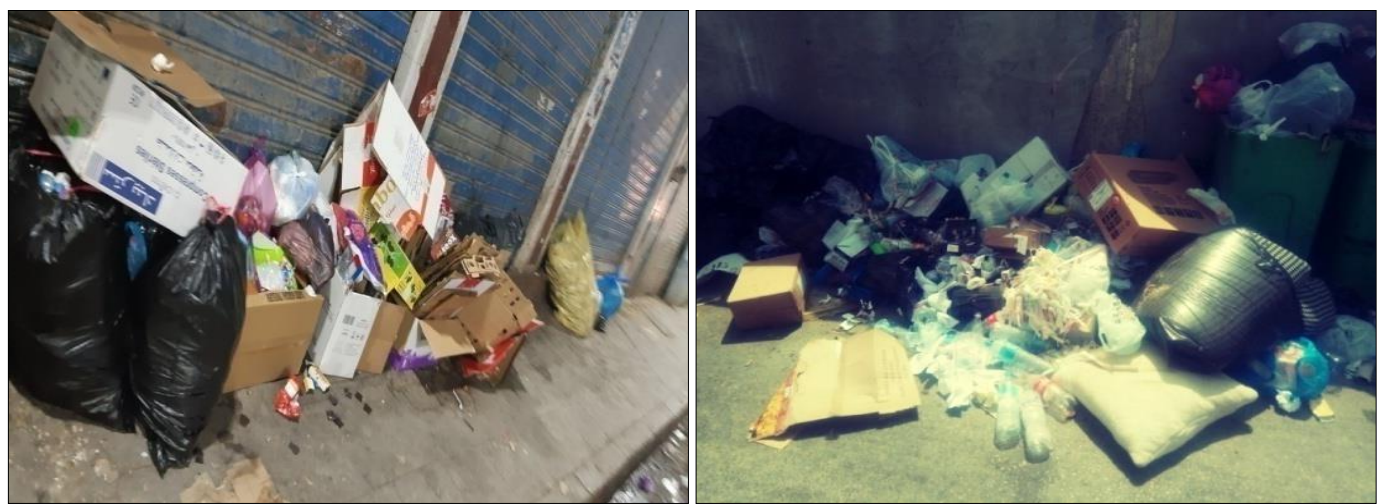

Figure 14. The considerable effects of waste on the living conditions of theinhabitants of the cityof Bejaia (Source: authors, 2021)

TOWARDS THE INTEGRATION OF PARTICIPATORY LOCAL MANAGEMENT IN THE CITY OF BEJAIA

The worrying record of environmental citizenship in the city of Bejaia in terms of the management of household and similar waste has prompted us to integrate participatory local management. This approach will focus on collaborative work between the inhabitants of the city of Bejaia, thus, working on the inclusive involvement of the citizen in all management actions. This approach will train us to register for rational waste management, thus addressing a certain level of ecological and economic resilience (figure 15). 


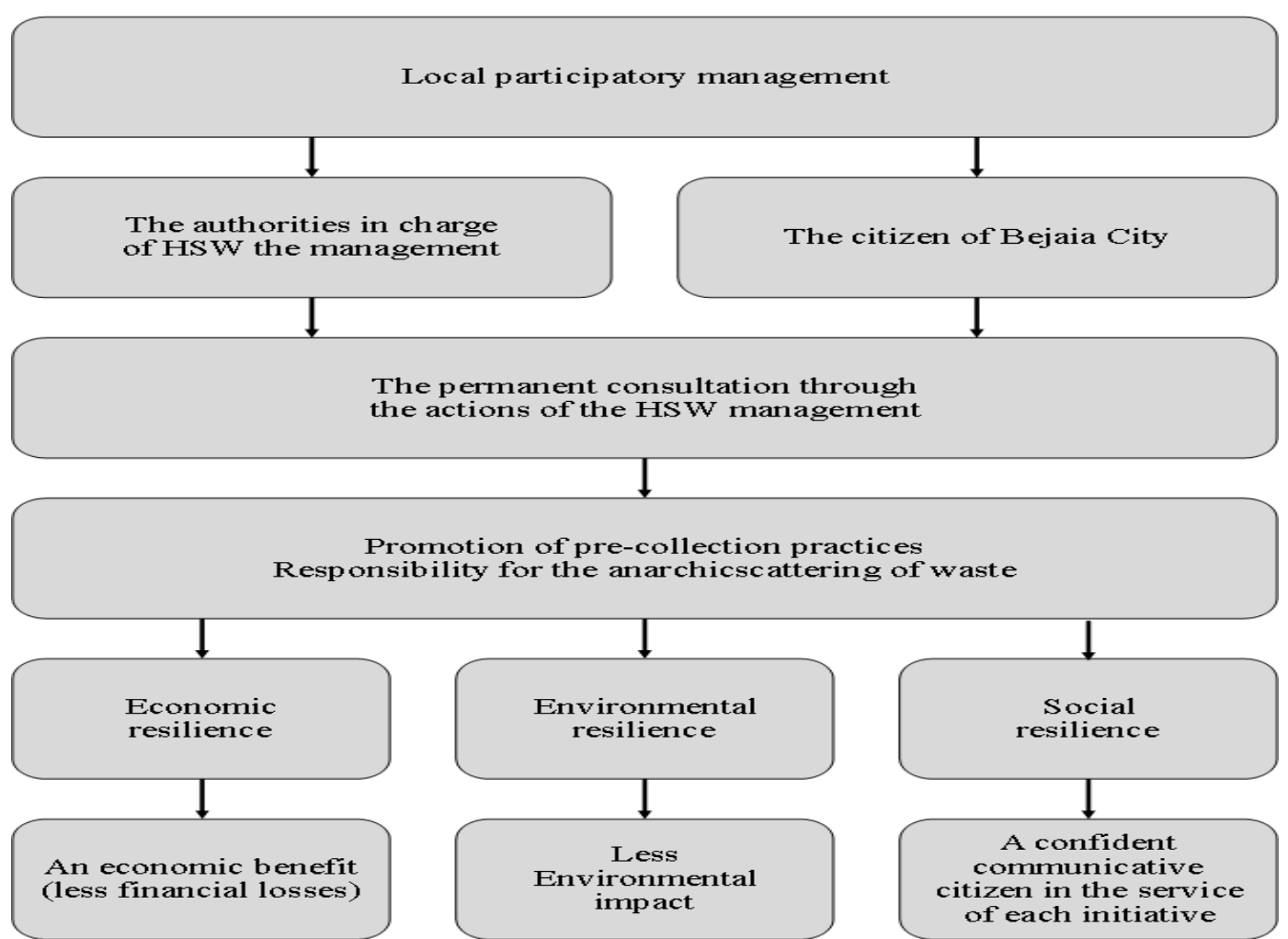

Figure 15. Integration methodology of environmental citizenship into the management of HWS in the city of Béjaia

(Source: Authors, 2021)

\section{CONCLUSION}

The problematic of household and similar waste management remains an absolute priority for the inhabitants of the city of Bejaia.But also a responsibility to be highlighted between all the users of this territory (the city of Béjaia).

To this end, this study came to present the reality of the management of household and similar waste in the city of Bejaia; we based on the presentation of the level of environmental citizenship of the inhabitants between rights and duties. The citizen, who has a right to a healthy living environment that is less polluted, has a responsibility to contribute to building the image of his city and the well-being of social groups in the city of Béjaia.

The observation of the city of Bejaia in terms of the management of household and similar waste led us to record several observed effects and declared that environmental citizenship is less expressed and remains restricted. This by contributing to the anarchic scattering of household and similar waste across all sectors of the city. A result of the inadequacies and practices recorded in the inefficient operations of the pre-collette as well, a management deficit on the part of the authorities responsible for the management of household and similar waste has accentuated the situation in the city of Béjaia. The consequences of the absence of a rational management influence firstly on the living environment of the inhabitants, secondly, it offends the tourist vocation of the city of Béjaia.

To this end, the results of the investigation allow us to put a result of this worrying situation. We opted for the integration of management shared between the citizen and the agency responsible for the management of household and similar waste (cleaning center of the city of Béjaia). Those in charge must invest in the citizen by informing and raising awareness about their duties, to make them a driving force behind every initiative, capable of registering positive behavior in the 
management of household and similar waste in the city of Béjaia. The recourse to correct all the difficulties remains the authotities responsible for the management of household waste and assimilated a request to implementation.

The problematic of household and similar waste management, its success is based on the degree of environmental citizenship of users of the city of Bejaia (inhabitant, merchant and tourist, etc.). Environmental citizenship considered as a cornerstone of rational waste management household and assimilated of the city of Béjaia which can assert a certain level of ecological and economic resilience.

\section{REFERENCES}

Algerian Ministry of Environment and Renewable Energy. (2020). Report of Algerian Ministry of Environment and Renewable Energy.

Algerian National Waste Management Strategy. (2016). Report of Algerian National Waste Management Strategy.

Algerian National Waste Management Strategy. (2019). Report of Algerian National Waste Management Strategy.

Algerian National Waste Management Strategy. (2020). Report of Algerian National Waste Management Strategy.

Bates, J., Murdie, R., \& Rhyne, D. (1996). Monitoring Quality of Life in Canadian Communities: A Feasibility Study. Canada Mortgage and Housing Corporation.

Béjaia City Administration. (2010). Master Plan for Development and Town Planning of the Municipality of Bejaia.

Béjaia City Administration. (2021). Béjaia City Planning Technical Service Report.

Bejaia Waste Management. (2020). Bejaia Waste Management Report.

Cutter, S. (1985). A geographer's view on quality of life. Washington: Asoociation of American.

Larousse. (2021). Dictionnaire de français. Retrieved from https://www.larousse.fr/dictionnaires/francais

National Office of Statistics. (2008). General Census of Population and Housing.

National Office of Statistics. (2015). Statistical yearbook of the city of Bejaia.

National Office of Statistics. (2019). Demographic Statistical Data. Bejaia. Retrieved from Socio economic Statistics of Algeria.

Renwick, R., Brown, I., \& Nagler, M. (1996). Quality of life in health promotion and rehabilitation: Conceptual approaches, issues, and applications. Sage Publications.

Sonko, S., \& Deac, A. (2020). From Simple Tourism to Smart Tourism: The Bet for the Development of a Responsible and Sustainable Tourism. Cases in the Ziguinchor Region (Senegal). Analele Universităţii din Oradea Seria Geografie, 30(1), 10-19. doi:10.30892/auog.301102-838

Vedura, T. (2021). Responsable Consumption and Sustainable Development. Retrieved February 25, 2021

*** (2010). Monographie of City of Béjaia.

Submitted:

May 01, 2021
Revised:

December 15, 2021
Accepted and published online December 22, 2021 